a thing to be avoided we have avoided it. We have made our start by treating education as a single and indivisible whole-and by trying to keep the different kinds of students in one organisation. How powerful this tendency is we may see by the example of Cambridge. We have done even more, for we have developed in connection with our new universities a system of evening teaching for a separate class of student. That the tendency to recognise this kind of instruction as legitimate for the British university is increasing appears when we look at such cases as those of Glasgow and Manchester, where the great technical colleges of these cities are being brought into the closest relation with their universities. I believe this to be entirely right, and I am glad that you in Bristol took the same course at the beginning when you brought the Merchant Venturers' College, with its evening teaching, into your new University organisation.

Specialisation in each city university there will be and ought to be. Non omnia possumus omnes. In one place the distinctive strength will be in chemistry - general and applied-for exist without each other they cannot. In another, as in Sheffield, it will be the metallurgy of iron and steel; and it is not unimportant in this connection that Sheffield is the chief centre for the manufacture of the national guns and steel plates, an industry in which we dare not dispense with high science. In another place, as in the case of the Imperial College in London, we should have the great training place in the metallurgy of the precious metals for the students of a people which leads the world in their production. Some universities will be strong in engineering, civil and mechanical, or, it may be, marine. But the one thing requisite is that the broad foundations of the highest general knowledge should be there in each university, and that all specialisation should rest on these foundations. You cannot, without danger of partial starvation, separate science from literature and philosophy. Each grows best in the presence of the others. Another essential feature is adequate provision for the postgraduate student-that is, the student who, having taken his degree, has in him the passion for excellence sufficiently strong to desire to continue in the university as a place of research and of the still higher learning which is inseparable from research. Such students may not be numerous, but when they are present they leaven the whole lump, and by their presence give a distinction to the university and to the professors under whom they work which could not be possible in their absence.

\section{WILLIAM BOTTOMLEY.}

$\mathrm{T}^{\mathrm{H}}$ HE death of William Bottomley at Glasgow on October 19, at sixty-three years of age, removes one who, throughout the greater part of his life, did genuine, unobtrusive service to the cause of applied science by the assistance he gave to his uncle, Lord Kelvin. A son of the late Mr. William Bottomley, of Fortbreda, County Down, and of Anna Thomson, the second of Lord Kelvin's sisters, Bottomley was trained as a civil engineer. In 1872 , Sir William Thomson and Fleeming Jenkin undertook to act in partnership as engineers for the manufacture and laying of telegraph cables which were to connect the cities of the Brazilian coast, from the Amazon to the River Plate. Bottomley was put in charge of a staff of young assistants at the works of the
Hooper Company at Millwall Docks where the cable was being made.

In those days there were no college laboratories which could compare with the testing-room of a cable factory as a scientific training ground for the practical electrician. The writer, who was a very junior member of the staff, well remembers Bottomley's cheery kindness, his capacity for management, and the ardour with which he threw himself into what was then a novel task. The art of cable testing, the necessities of which had been a chief factor in bringing into existence the scientific system of electrical units, was still undergoing evolution: new methods had to be devised, tested, and licked into shape for everyday use.

In I873, Bottomley, along with his colleague W. F. King, accompanied Thomson and Jenkin in the maiden voyage of the cable ship Hooper, when the first section, from Para to Pernambuco, was laid. The sections from Pernambuco southward were laid in subsequent expeditions under their supervision, and in the absence of the chiefs.

Probably there are few parts of the later work of Kelvin in applied science with which William Bottomley was not in some degree concerned. With the Kelvin compass he had an early and intimate association. When the long struggle was over which preceded its general acceptance in the Navy and the mercantile marine, the task of looking after it as an article of manufacture and an object of business enterprise fell mainly on his shoulders. He had to train and superintend the skilled compass adjusters whose services were essential to its success. His own energy, his tact and judgment, and his appreciation of the scientific points at issue were in constant exercise for many years with the happiest results. The Kelvin compass came into universal use primarily, of course, because of its intrinsic merits; but these had to be demonstrated, defects had to be corrected, and prejudices to be overcome. In this work Bottomley's unfailing geniality, his simplicity and directness, and the warmth of his enthusiasm were valuable adjuncts to his technical knowledge : they were qualities, too, that endeared him to his friends.

J. A. E.

\section{PROF. LEWIS BOSS.}

$\mathrm{T}$ is with deep regret that we have to record 1 the death of Prof. Lewis Boss on October 5. While working as an assistant astronomer on the U.S. Northern Boundary Commission in 1877 , Prof. Boss was greatly impressed by the urgent necessity for greater accuracy in star catalogues, and forthwith made the remedying of the defect his life-work; the immediate outcome was the extremely valuable "Boss's Declinations," in which, after discussing some hundred catalogues, he gave the declinations and proper motions of 500 stars for the epoch 1875 . In 1878 he was appointed director of the Dudley Observatory, Albany, N.Y., a position which he held until his death, and after observing the corona at the solar eclipse of that year, he settled down to the solution

No. 2243, VOL. 90] 
of the many problems involved in the rigid determination of stellar positions. Generous friends showed their appreciation of Prof. Boss's labours by providing him with a new observatory in 1893, and later the Carnegie Institution of Washington showed practical sympathy with his work, also making him director of the Meridian Astrometry Department of the Institution.

Prof. Boss's publications are too many to refer to in detail here, but they dealt with many subjects such as the instrumental and magnitude errors in meridian work, the observation of comets, for which he published many ephemerides, and the determination of the sun's motion. In 1903 he published a standard catalogue of 627 stars distributed over both hemispheres, and in Igro a preliminary general catalogue, in which he gave positions and proper motions of 6188 stars, of which about 4000 are brighter than the sixth magnitude.

The value of these researches is inestimable, but already many important results have accrued, such as the discovery of the Taurus stream of stars, and the value will rapidly advance as time passes. In I905 the Royal Astronomical Society recognised Prof. Boss's work by presenting him with its gold medal, and in England, as elsewhere, the loss of a great and original investigator, and a personal friend, will be sorely felt. Prof. Boss was born at Providence, R.I., in 1846 .

\section{NOTES.}

THE Huxley lecture at the University of Birmingham is to be delivered on October 30 by Prof. John Joly, F.R.S., who has chosen as his subject "Pleochroic Halos."

THE annual Huxley memorial lecture of the Royal Anthropological Institute will be held on Tuesday, November 19, at 8.30 p.m., at the theatre of the Civil Service Commission, Burlington Gardens, London, W., when Prof. W. Gowland, F.R.S., will deliver an address on "The Metals in Antiquity." Dr. Alfred P. Maudsley, president, will take the chair.

THE Institute of Chemistry announces that Mr. E. White will deliver a lecture on thorium and its compounds on Friday, November I, at 8 p.m., in the Chemical Lecture Theatre of Finsbury Technical College, London, E.C. Prof. R. Meldola, F.R.S., president of the Institute, will occupy the chair.

Prof. E. Metchnikoff, of the Pasteur Institute, Paris, will deliver a lecture on "The Warfare against Tubercle" in London on Friday, November 29, at 4.30, at the Royal Society of Medicine, Wimpole Street, Cavendish Square. The lecture is the Lady Priestley memorial lecture for 1912 .

Much interest was aroused last March by the discovery of typical Upper Old Red Sandstone with fish remains beneath the neighbourhood of London. Mr. E. Procter, of the Imperial College of Science, exhibited to the Geological Society characteristic fragments of Holoptychius and Bothriolepis, which he had obtained from a depth of between 1100 and 1200 feet NO. 2243 , VOL. 90] in a boring at Southall. He has lately presented these specimens to the British Museum (Natural History), where they are now to be seen among the fossil fishes.

Peabody Museum, Yale University, has received from the assistant professor of archæology, Dr. G. G. MacCurdy, the anthropological collections made by him during his summer visit to Europe. It has also acquired 2000 geological specimens gathered by Prof. C. Schuchert in Nova Scotia and the Lake Huron region, a collection made at Abydos in connection with the Egyptian exploration fund, and remains of a fossil three-toed horse found in Texas by Prof. R. S. Lull.

THE death is reported, within a few days of his seventieth birthday, of Mr. Bradford Torrey, well known in America as a naturalist. He was a frequent contributor to The Atlantic Monthly, and was for several years one of the editors of The Youth's Companion. He had edited Thoreau's Journal, and was himself the author of "Birds in the Bush," "A Rambler's Lease," "The Foot-path Way," "A Florida Sketch-book," "Spring Notes from Tennessee," "A World of Green Hills," "Footing it in Franconia," "The Clerk of the Woods," "Nature's Invitation," and "Friends on the Shelf."

DR. MORRIS LOEB, for several years professor of chemistry at New York University, died recently in his fiftieth year. He was a member of the executive committee of the International Congress of Applied Chemistry, which met a few weeks ago in America. His own research work was done chiefly in complex inorganic salts. Last year Dr. Loeb presented 10,oool. to the Walcott Gibbs Chemical Library at Harvard, of which university he was a graduate, and he was a generous benefactor of various scientific societies and Hebrew charities. He had been president of the Hebrew Technical Institute and of the Chemists' Club, and was a member of the New York Board of Education.

THE death is announced, at sixty-eight years of age, of Mr. Robert Brown, fellow of the Society of Antiquaries, and distinguished by his works on comparative mythology. He was (says The Times) a student of Chaldæan myths, agreeing with Prof. Max Müller in tracing their origin to the movements of sun, moon, and stars, and the ebb and flow of natural phenomena, and opposing strongly the rival theory of totemism. His chief work, "The Great Dionysiak Myth" (two vols.), appeared in $1877-8$, and he also published "The Myth of Kirke," "Aratus," "Researches into the Origin of the Primitive Constellations of Greeks, Phonicians, and Babylonians," (two vols.), and "Semitic Influence in Hellenic Mythology."

WE regret to learn from The Times that Prof. Otto Krümmel, who held the professorship of geography for many years at Kiel, and latterly at Marburg, and was recognised as the leading German oceanographer, died suddenly on October 12, at fifty-eight years of age. In I9II he completed the publication of a standard treatise on oceanography, and he was joint author of the article, "Ocean and Oceanography," in the xith edition of the "Encyclopædia Britannica." 